\author{
Martina IVAnOVÁ \\ Inštitút slovakistických, mediálnych a knižničných štúdií \\ Filozofická fakulta Prešovskej univerzity v Prešove
}

\title{
Synchrónia a diachrónia v Slovníku koreňových morfém slovenčiny*
}

Kl’úč ové slová: súbor radixov, slovotvorné hniezdo, demotivácia

Práca na slovníku morfematicko-derivačného charakteru, akým je Slovník koreňových morfém slovenčiny $\left(2005,2007\right.$, d’alej SKMS $\left.{ }^{1}\right)$, zahíňala primárne zachytenie slovotvorných procesov odohrávajúcich sa v lexikálnej rovine jazyka. Je prirodzené, že v tejto súvislosti pred autormi vyvstali dve fundamentálne otázky: 1. s akou základnou systemizačnou jednotkou reflektujúcou morfematicko-derivačné vzt’ahy medzi lexémami pri koncipovaní slovníka pracovat' a 2. akým spôsobom sa vyrovnat's dynamickou povahou formálno-sématických vztahov, teda ako zachytit' demotivačné procesy, ktoré sa svojou procesuálnou povahou jednoznačnej systemizácii „Vzpierajú”.

Charakter slovníka založeného na systemizácii jednotiek na základe radixov viedol $\mathrm{k}$ nutnosti pracovat's rovnakokoreňovými paradigmami jednotiek. V derivatológii rovnakokoreňový typ slovotvorného útvaru reprezentuje slovotvorné hniezdo. Morfematická povaha slovníka však viedla k potrebe vymedzit’ ako základnú systemizačnú jednotku útvar, ktorý okrem jednoznačne

* Táto práca vznikla v rámci riešenia projektu VEGA č. 1/0102/09 Elektronické spracovanie anglických vlastných mien $v$ slovenčine.

${ }^{1}$ Všetky štatistické závery vychádzajú z analýzy druhého, upraveného vydania Slovnika koreňových morfém slovenčiny (2007) realizovanej prostredníctvom programu Excel. 
jestvujúcich derivačných vzt’ahov medzi jednotkami s identickým radixom bude zachytávat' aj vzt’ahy zo sémantického či formálneho hladiska deaktualizované. Takou jednotkou sa stal súbor radixov. Systemizácia prostredníctvom súboru radixov a prostredníctvom slovotvorných hniezd sa opiera o polysémiu koreňových morfém, prostredníctvom ktorej môže jeden súbor radixov združovat' niekol'ko slovotvorných hniezd na základe diachrónneho alebo sémantického usúvzt’ažnenia primárnych motivantov.

Jedným z prvých klúčových krokov bolo odlíšenie polysémie a homonymie radixov. Radixová polysémia a radixová homonymia sa vymedzuje $\mathrm{v}$ rámci radixov s asymetriou jednej formy a viacerých významov (porovnaj Sokolová, Genči 2006).

Radixová homonymia sa v SKMS naznačuje horným indexom. Štatistické výskumy preukázali, že v SKMS sa vymedzuje celkovo 825 homonymných radixov (Sokolová, Genči 2006). V SKMS sa dôsledne selektuje homografia a homofónia monosémických koreňových morfém, homografickost' radixov sa eliminuje fonetickým zápisom koreňových morfém. Homonymia radixov vzniká pri preberaní lexikálnych jednotiek: môže íst' o homonymiu domáceho a prevzatého radixu (MOT ${ }^{1}$ - motor, internacionálny radix pôvodne z latinčiny, $\mathrm{MOT}^{2}$ - motat', domáci radix) alebo o homonymiu radixov prevzatých z rôznych jazykov $\left(\mathrm{MAN}^{1}-\right.$ manuál, pôvodom latinský radix, $\mathrm{MAN}^{2}$ - manometer, pôvodom grécky radix). V takýchto prípadoch možno hovorit' o interlingválnej heterogénnej homonymii radixov.

V prípade diachrónnej sémantickej dekorelácie medzi významami polysémickej jednotky sa v diachrónnej lexikológii uvažuje o tzv. historickej alebo homogénnej homonymii (porovnaj Dolník 2003), ktorá sa realizuje pri sémantickom rozštiepení významu. V našom spracovaní sa prípadná homogénna homonymia radixov nespája s vymedzením osobitnej homonymickej koreňovej morfémy, diachrónne usúvztažnené primárne motivanty sú príslušníkmi dvoch osobitných slovotvorných hniezd, ale jedného súboru koreňových morfém. Nazdávame sa, že práve takýto spôsob riešenia umožňuje zachytit' obe stránky skúmaného javu: demotiváciu ako synchrónny lexikálnosémantický jav a zároveň diachrónnu „motivačnú históriu” založenú na sémantickej súvzt’ažnosti radixov.

Pri odlíšení homonymných a polysémických radixov dôležitú úlohu zohráva tzv. etymologická homonymia radixov. Iba na jej základe možno identifikovat' náhodnú formálnu podobnost', nejednoznačnost’ priradenia jed- 
notky k dvom formálne identickým radixom, resp. „silu” motivácie, ktorá umožňuje interpretovat' zdanlivý motivačný vztah medzi sémanticky alebo geneticky nemotivovanými radixmi.

Ako príklad náhodnej formálnej podobnosti možno uviest' spracovanie jednotky pochlebovat. Primárne sme jednotku klasifikovali v rámci radixu CHLIEB s východiskovým motivantom chlieb. Geneticky však ide o odlišné, sémanticky rozlíšené radixy, chlieb je prevzatie z germánčiny, pochlebovat' je zasa od chalba s významom „lichotenie” (porovnaj Machek 1968). Dôsledkom identifikácie etymologickej homonymie radixov v lexikografickom opise je spracovanie príslušných jednotiek v rámci dvoch samostatných súborov radixov, čoho dôsledkom bola dezintegrácia pôvodného slovotvorného súboru s jedným polysémickým radixom.

„Sila” motivácie v podobe tzv. remotivácie (k termínu remotivácia pozri Furdík 1993: 26) sa prejavuje aj v usúvzt’ažňovaní jednotiek, ktoré sú z etymologického hladiska homonymné, napr. motivanty koč a kočovat' sa pôvodne spracovávali v súbore s radixom KOČ (a to na základe možnej sémantickej motivizácie kočovat' ,presúvat' sa z miesta na miesto pomocou koča”), avšak aj v tomto prípade ide o etymologickú homonymiu radixov: koč je z pravdepodobne z mad’arčiny a je výsledkom apelativizácie (pôvodné toponymum Kocs), kočovat' je zasa z turkotatárskeho köc vo význame „cesta, presídlenie" (porovnaj Machek 1968). Výsledkom rešpektovania etymologických súvislostí dochádza pri spracovaní $\mathrm{k}$ dezintegrácii pôvodného súboru radixov a k vzniku dvoch homonymných radixov. Prípadné remotivačné tendencie sa v spracovaní eliminujú perintegráciou v rámci radixu, porovn. napr. radixy HAL' (halit'sa) a HALEN (halena - prevz. z turkotatárčiny, pôvodne hal-in-a).

Na základe uvedených faktov možno konštatovat', že medzi súborom koreňových morfém a slovotvorným hniezdom sa môžu realizovat' tri typy vzt’ahov:

a) Ekvivalentná distribúcia

Ide o najfrekventovanejš́ typ vzt’ahu, pri ktorom jeden súbor radixov zahŕňa jedno slovotvorné hniezdo s jedným východiskovým motivantom. V takom prípade ide o monosémickú koreňovú morfému.

b) Jednosmerná inkluzívna distribúcia

Pri tomto vzt’ahu obsahuje jeden súbor radixov aspoň dve slovotvorné hniezda s minimálne dvoma východiskovými motivantmi. Základom spraco- 
vania radixov v rámci osobitných slovotvorných hniezd, ale jedného súboru radixov je sémantická súvzt’ažnost' primárnych motivantov. Táto sémantická súvztažnost' sa zakladá na prítomnosti spoločného sémantického komponentu, ktorý sa realizuje pri primárnych motivantoch jednotlivých slovotvorných hniezd.

Z formálneho hl'adiska je súbor radixov štruktúrovaný tak, že ako prvé sa spracúva slovotvorné hniezdo s formálne a sémanticky nemotivovaným východiskom, na d’alšom mieste sa spracúvajú slovotvorné hniezda s motivantmi, ktorých formálna štruktúra i motivačná história odkazujú na pôvodnú motiváciu. Spoločný sémantický príznak, na základe ktorého sú slovotvorné hniezda združené do jedného súboru radixov, má v pôvodnom motivante zväčša povahu fakultatívneho alebo implikovaného príznaku, v lexikálnom význame demotivovanej jednotky zasa povahu kriteriálneho komponentu (napr. jež „zviera s pichliačmi”, fakultatívny príznak [vzpriamený] sa stáva kriteriálnym komponentom vo význame jednotky ježit',,vzpriamit' do kolmej polohy”).

Diskontinuita medzi významom pôvodného motivantu a príslušného sémantického komponentu môže mat' viacero stupňov, čo možno demonštrovat' súborom s radixom HOR. V prípade primárnych motivantov horiet' a horú$c i$ ide o spoločný sémantický komponent [teplota] (horiet' „proces spal'ovania, pri ktorom vzniká teplota”, horúci „majúci vysokú teplotu”), ktorý je súčastou invariantného jadra lexikálneho významu, v prípade jednotky horúci je tento sémantický komponent súčastou tzv. intenzionálnej zóny významu, v prípade jednotky horiet' zasa vystupuje ako tzv. silný implikačný komponent (Nikitin 1983, citované podla Dolník 2003). Vyššiu mieru diskrepancie medzi pôvodným lexikálnym motívom a obsahovým komponentom jeho motivátu reprezentuje jednotka horlivý, kde sémanický komponent [vysoká teplota] má povahu tzv. slabého implikačného komponentu, ktorý sa stáva derivačným základom pri transpozícii pôvodného lexikálneho motívu.

V prípade súborov s dvoma východiskovými motivantmi sa môže realizovat' aj tzv. izolovaná demotivácia, ktorá vzniká vtedy, ked' si demotivovaná jednotka nezakladá vlastné slovotvorné hniezdo. ${ }^{2}$ Izolovaná demotivácia

2 Do úvahy treba, samozrejme, brat’ aj fakt, že ako prípady izolovanej demotivácie sú uvedené aj také prípady, pri ktorých i demotivované jednotky zakladajú vlastné slovotvorné hniezdo, avšak v SKMS tieto jednotky nie sú zachytené, ked’že materiálovou základňou slovníka bol Krátky slovník slovenského jazyka (1997) a Pravidlá slovenského pravopisu (2000). 
sa často vyskytuje v prípade pôvodne motivovaných zoologických, resp. botanických názvov, pričom lexikálna motivácia nie je vždy celkom sémanticky transparentná, v niektorých prípadoch ide o sémantické kalkovanie, napr. jarabina, jahňada, piskor atd'. V uvádzaných prípadoch sa lexikálnym motívom stáva similaritný príznak entity, ktorý však nemá kriteriálnu povahu. Napríklad v prípade demotivovanej jednotky jahňada sa základom motivácie stal príznak „majúci jemné biele kvety a oblý tvar ako jahňa”.

c) Nulová distribúcia

Takýto vztah sa realizuje v prípadoch, ked’ je súbor radixov jednoprvkový, neobsahuje teda ani jedno slovotvorné hniezdo, alebo v prípadoch, ked' súbor radixov obsahuje sémanticky alebo diachrónne usúvzt’ažnené lexikálne jednotky, ktoré nevystupujú ako motivanty, netvoria teda slovotvorné hniezda. Ide o jednotky nezapojené do vzt’ahov slovotvornej motivácie z periférie lexikálnej zásoby, t. j. jednotky expresívne, interlingválne, štylisticky alebo temporálne motivované, ktorých slovotvorný motivačný potenciál je nulový alebo vel'mi malý, napr. fištrón, fitfirit', odkundes, etablishment, estakáda, gebul'a, gebuzina.

Radixová polysémia sa v SKMS (2007) vyskytuje v 1039 prípadoch a naznačuje sa plnou bodkou. Počet primárnych motivantov v súbore zachytáva nasledujúca tabul'ka:

\begin{tabular}{|l|c||}
\hline \multicolumn{1}{|c|}{ Primárne motivanty v súbore } & Počet \\
\hline súbory s 2 motivantmi & 636 \\
\hline súbory s 3 motivantmi & 203 \\
\hline súbory so 4 motivantmi & 78 \\
\hline súbory s 5 motivantmi & 44 \\
\hline súbory so 6 motivantmi & 23 \\
\hline súbory so 7 motivantmi & 12 \\
\hline súbory s 8 motivantmi & 12 \\
\hline súbory s 9 motivantmi & 5 \\
\hline súbory s 10 a viac motivantmi & 26 \\
\hline Spolu: & $\mathbf{1 0 3 9}$ \\
\hline
\end{tabular}

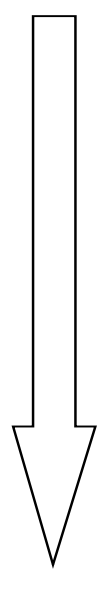


Ukazuje sa, že najviac zastúpený typ je súbor radixov s dvoma primárnymi motivantmi, najvyšší počet primárnych motivantov v jednom súbore je 96 pri radixe LOG. V prípade súborov s vysokým počtom primárnych motivantov sa príslušné polysémne radixy realizujú najmä v kompozitných jednotkách a práve táto frekvencia môže byt' jedným z prvých ukazovatel'ov delexikalizácie a afixoidizácie radixu, porov. radixy v komponentoch grafia (56), meter (36), skop (27), bi (22), fil (17).

Polysémia radixov sa v slovníkovom zachytení je daná viacerými faktormi:

\section{Absencia motivantu}

Napriek absencii motivantu možno na základe slovotvorného systému predpokladat' jeho existenciu, či už ako potenciálnej jednotky, alebo ako jednotky jestvujúcej v jazykovom úze, ktorej existenciu možno overit' v korpuse. V takomto prípade vyčleňujeme tzv. hypotetický motivant (porovnaj Sokolová, Ivanová, Dziaková 2003). Pri absencii motivantu sa rozčlenenie súboru do viacerých slovotvorných hniezd spája s viazanostou koreňovej morfémy. Radixová polysémia je v SKMS (2007) podmienená absenciou motivantu v 528 prípadoch $(50,8 \%)$, z toho pri domácich jednotkách sa radixová polysémia spôsobená absenciou motivantu vyskytuje v 88 prípadoch $(8,46 \%)$ a pri prevzatých jednotkách v 440 prípadoch (42,3\%).

Absencia motivantu môže byt' podmienená viacerými faktormi:

a) Ide o interlingválny motivant z iného jazyka, ktorý v slovenskom jazyku nejestvuje, resp. nie je zachytený v slovníku. Práve pre prevzaté jednotky je charakteristická absencia primárneho motivantu, resp. niektorého člena slovotvorných radov a paradigiem: lingv-istika - bi-lingv-izmus (*LINGV), imagin-ácia - imagin-árny (*IMAGIN), rozo-rvat' - vy-rvat' srdve-rv-úci (*RV). Napriek hypotetickosti motivantu v takýchto príkladoch často pôsobí tlak slovotvornej analógie, ktorý vedie $\mathrm{k}$ tomu, že sa k prevzatej jednotke môže utvorit' jednotka, ktorá začne fungovat' ako jej východiskový motivant. V takom prípade dochádza $\mathrm{k}$ remotivácii pôvodne nemotivovanej jednotky a k integrácii pôvodne rozlíšených slovotvorných hniezd, napr. (exponovat') - (>) expozícia.

b) Ide o teritoriálne, stratifikačne alebo temporálne príznakový hypotetický motivant (k pojmom teritoriálna, stratifikačná a temporálna motivácia pozri Furdík 2008), ktorý nie je zachytený v KSSJ: jun-ák-jun-ec, blaf-ovat'-o-blaf-nút', gomb-ík-gomb-ička, resp. 
nezachytenie motivantu v príslušnom type slovníka, porov. radixovú polysémiu v prípade jednotiek neogabaný - ogabat'(gabat' ${ }_{\text {reg }}$ : SSSJ 2006), egoizmus - egocentrik ( ego $_{\text {filoz: }}$ : SSSJ 2006).

c) Ide o nesklonný motivant, ktorý nie je zachytený v slovníku: [A] $a^{-}$-čko-á-čka - a-be-ce-d-a, [C] cé-čko - cé-čka - cé-dečko-a-be-ce$d-a,[\mathrm{G}] \mathrm{gé}-\mathrm{c} k o-g e ́-c ̌ k a$.

d) Ide o absenciu verbálneho motivantu pri morfematicky segmentovatel'ných jednotkách (typická najmä pre domáce jednotky): (*bŕdnut') pre-bŕdnut' - vy-bŕdnut'-z-bŕdnut; ( 'česnút') od-česnút' - roz-česnút'; (*drhat') o-dr'hat'-od-dr'hat'-za-dr'hat'; (*hajdákat') pre-hajdákat'-roz-hajdákat'; ('hŕknut') ob-hŕknut'-v-hŕknut'-vy-hŕknut'-z-hŕknut'.

e) Ide o absenciu onymického motivantu: v tomto prípade vznikajú v súbore radixov viaceré slovotvorné hniezda bud' kvôli A) absencii onymického motivantu v slovníkovom zachytení (napr. [Lenin] - zdanlivo nemotivované lexémy leninovec, leninizmus, leninský), alebo B) pri onymických jednotkách, ktoré v príslušnej forme jestvujú len v inom jazyku (napr. *HUNGAR - hungaristika, hungarizmus, hungarizácia).

Absencia východiskového motivantu znamená, že radixy lexém patriacich do jednej slovotvornej paradigmy (so spoločným onymickým motivantom) sme boli nútení uvádzat’ ako polysémne.

\section{Variantnost' motivantov}

Variantnost' je charakteristická najmä pre domáce jednotky, v SKMS sme zaznamenali 26 prípadov (2,5\%) radixovej polysémie danej variantnostou primárnych motivantov. Najčastejšie ide o tieto prípady:

a) Alternačne nepodmienené varianty koreňových morfém on o ma to p ojí, pri ktorých sa jednotlivé varianty líšia imitačnou dominantou (konsonantickými fonémami), resp. imitačnou premennou (vokalickými fonémami), napr. ach/áh/ach/ach-och/oh/óh, ha-ha-hi-hi, cho-cho - chu-chu, ceng-cing-ciling, cvrk-cvrli-čvrli-svrk. Radixová polysémia sa uplatňuje v prípadoch, ked' varianty vytvárajú vlastné slovotvorné hniezdo $\mathrm{s}$ istým počtom motivátov, napr. ha-ha, he-he, hi-hi-> hihúñat' sa; chal cha-cha, che-che-> chechtat' sa, > zachechtat'sa. V opačnom prípade ich SKMS vymedzuje ako spoločný východiskový motivant, napr. fi/fí-> fičat', $>$ zafičat'. 
b) Pronominálne varianty, často s potenciálnymi morfematickými hranicami: k[ade] - k[adial'] - odk[ial'] - pok[ial'] - zak[ial'], k[edy] pok[ial'] - k[ým], t[ade]-t[adial']-zat[ial'].

c) Fonologické a morfematické varianty: blesnút'-blysnút' - blesknút' - blysknút', huhlat' - huhnat', kvacknút' - kvicknút', drgáňat'sa-drgál'at'sa, red'kev-red'kovka.

d) Perintegrácia pôvodných morfematických švíkov $\mathrm{v}$ domácich aj prevzatých jednotkách: vnútro - útroby, viat' - vietor, abbé abatiša, fantázia - fantazmagória.

e) Supletívnost' primárneho motivantu: pri supletívnych typoch sa radixová polysémia uplatňuje $\mathrm{v}$ prípadoch, ked' súbor radixov pozostáva $\mathrm{z}$ viacerých slovotvorných hniezd a motiváty sa prirad’ujú $\mathrm{k}$ motivantom na základe formálnej podoby supletívneho radixu. Supletívnost' je charakteristická pre domáce jednotky: človek - l'udia, jeden - prvý, dva druhý. Prípady so supletívnym radixom fungujú ako jeden spoločný východiskový motivant:

f) Prevzaté jednotky, pri ktorých je variantnost' vedúca k radixovej polysémii zriedkavejšia (len 14 zaznamenaných prípadov), vzniká pri adaptácii internacionalizmov (KRSŤ / CHRIST / KRESŤ, FAKS / FAX, ACCELER / AKCELER, KONCERT / CONCERT) a môže sa spájat' so sémantickou (spirituál-špirituál, rock-rockandroll, koncert-concertino), prípadne štýlovou diferenciáciou jednotiek (odb. diskurz - hovor. diškurz). Variantnost' môže byt' motivovaná stavom a zmenami vo východiskovom jazyku (porovn. glukóza - glycerín z gr. gleukos, glykeros) alebo ide o sémanticky súvztažné jednotky s odlišným pôvodom, ktoré spracúvame v rámci jedného súboru radixov NERV / NEUR (NERV - lat., NEUR - gréc.).

3. Adaptačné procesy späté s transmorfologizáciou ${ }^{3}$

Ide tu o prípady sémanticky súvztažných prevzatých jednotiek, ktoré sa v rámci adaptačných procesov stávajú prvkami odlišných morfologických paradigiem. Radixová polysémia sa $\mathrm{v}$ dôsledku týchto procesov vymedzuje v 25 prípadoch $(2,4 \%)$. Ide prevažne o prípady neviazaných radixov: meter - metrum, bank - banka, metal - metál, hymna - hymnus, artikel - artikul. V prípadoch slovnodruhovej homonymie jednotky vo východiskovom jazy-

${ }^{3}$ K pojmu transmorfologizácia pozri Furdík (1994). 
ku je radixová polysémia výsledkom paralelných procesov transmorfologizácie a transderivácie, napr. cardinal $l_{\text {SUBST/ADJ }} \rightarrow$ kardinál (transmorfologizácia) - kardinálny (transderivácia), o vztahu slovotvornej a interlingválnej motivácie pozri bližšie Ološtiak 2007.

4. Strata formálnej a sémantickej súvzt’ažnosti s pôvodným motivantom

V takom prípade sa stráca sémantická korelácia medzi východiskovým motivantom a jedným z motivátov a výsledkom je odštiepenie daného motivátu z pôvodného slovotvorného hniezda a vznik radixovej polysémie. V SKMS sa radixová polysémia uplatňuje tak pri domácich (292 prípadov $28,1 \%$ ), ako aj pri prevzatých jednotkách (180 prípadov - 17,32\%).

J. Furdík (1993: 20-21) vo svojich úvahách o demotivačnom cykle rozlišoval demotiváciu na úrovni formy a demotiváciu na úrovni významu. Pri demotivácii na úrovni formy ako príčiny uvádza: 1 . absenciu motivantu (ide tu o prípad popísaný v bode 1); 2 . vysunutie pôvodného motivantu na perifériu lexikálnej zásoby (ide tu prípady popísané $\mathrm{v}$ bode $1 \mathrm{~b}$, pri spracovaní hesiel v SKMS sme v podstate vychádzali z prítomnosti, resp. absencie danej jednotky v KSSJ, demotiváciu nenaznačujeme, ak formálnu súvztažnost' daných jednotiek zabezpečuje použitie funkčne vyhraneného afixu, uplatnenie pravidelnej alternácie a pod., napr. dvojice húst' - hudba, ploský - ploštica sa v SKMS neevidujú ako demotivované); 3. prípady, ked’ sa prvky formálnej štruktúry stali neživými. V tomto prípade sa možno opriet' o slovotvornú štruktúru pôvodne motivovaného slova. V súvislosti so slovotvorným základom demotivácia prebieha ako strata formálnej súvztažnosti s motivantom alebo prostredníctvom využitia zriedkavých, resp. unikátnych formantov. V oboch prípadoch tak dochádza k oslabeniu alebo strate štruktúrnej priezračnosti derivátu. V SKMS demotiváciu nenaznačujeme v prípadoch využitia raritných či unikátnych formantov. $V$ tomto prípade je rozhodujúca sémantická korelácia s pôvodným motivantom: mäkk-ýš, košt'-ial', var-echa, obl-úk, mokr-ad'. Naopak, zachytenie demotivačných procesov vedúcich k radixovej polysémii sa uplatňuje v prípade málo frekventovaných a raritných alternácií, prípadne pri výraznej deformácii radixu, napr. ruka - naporúdzi, sat' - násoska, sunút'sa - sovok, dobrý-vel'kolepý.

${ }^{4}$ Súčet percentuálneho zastúpenia jednotlivých skupín je vyšší než 100 \%, pretože jestvuje súbor „prienikových” prípadov. 
Demotivácia na úrovni významu sa prejavuje ako oslabenie či strata korelácie medzi slovotvorným a lexikálnym významom. Demotivácia sa uplatn̆uje v prípade inklúzie a prieniku medzi slovotvorným a lexikálnym významom. Jednoznačne odlíšit' stupne demotivácie na úrovni významu je komplikovaná otázka, pretože hranice medzi jednotlivými stupňami sú prirodzene neostré. Pri lexikografickom spracovaní je však nutné jednoznačné spracovanie. SKMS tak uplatňuje tieto demotivačné stupne:

1. Prípady inklúzie založené na prototypickej alebo typickej motivácii v slovníku ako demotiváciu neinterpretujeme: napr. význam jednotky sokoliar sa v slovníku vykladá ako „chovatel' a cvičitel' pernatých dravcov” (chovatel' a cvičitel' sokolov je prototypovým exemplárom v tejto kategórii), podobne význam jednotky zlatnik je „odborník na výrobu, opravu a predaj drahých predmetov" (typickým predmetom z drahých kovov je zlato), význam jednotky občan je „obyvatel' štátu, mesta alebo obce” (pričom prototypovým exemplárom v tejto kategórii je obyvatel' obce). Hoci tieto jednotky nie sú hodnotené ako slovotvorne demotivované, pri inklúzii už možno pozorovat' odchýlky medzi slovotvorným a lexikálnym významom, čo môže byt' signálom - v závislosti od stability, resp. lability motivačného príznaku ${ }^{5}$ - naštartovania demotivačných procesov.

2. Na druhom stupni demotivačné procesy vedú k odštiepeniu jednotky z pôvodného slovotvorného hniezda. Jednotka síce zostáva súčastou príslušného súboru, nenaznačujeme však pri nej motivačný vzt’ah a spracúvame ju ako východiskový motivant. Výsledkom je vznik polysémického radixu. O demotivácii na úrovni významu, pri ktorej ide o prienik medzi slovotvorným a lexikálnym významom, možno uvažovat' v takýchto prípadoch:

a) Demotivácia spôsobená špecifikáciou lexikálneho významu pôvodného motivantu alebo generalizáciou významu motivátu

Jednou z príčin demotivácie jednotky môže byt’ špecifikácia lexikálneho významu pôvodného motivantu. Pribratím nového sémantického príznaku sa oslabuje motivačný vzt’ah medzi pôvodným motivantom a jeho motivátom, pre ktorý tento príznak nie je relevantný. Ako príklad možno uviest' demotiváciu jednotky kroj, pôvodne motivovanú slovesom krájat. Pôvodný lexikál-

\footnotetext{
5 Termín stabilita motivačného príznaku používa J. Dolník (1995).
} 
ny význam danej jednotky (,delit' na menšie kúsky, rezat', strihat”') bol rozšírený o sému syntagmatickej povahy (o potravinách), ktorá v motiváte kroj (kroj ako „to, čo sa kroji””, pôvodne išlo o výrobu odevu rezaním, strihaním kusov látok) nie je relevantná. Ďalšie príklady z SKMS: biblia - bibliotéka bibliografia, páter - pátričky, štet - štetec, veno - venovat'.

b) Demotivácia spôsobená deaktualizáciou a periferizáciou sémantického príznaku inkorporovaného v pôvodnom slovotvornom základe

Časté sú prípady, ked' príznak indikovaný pôvodným slovotvorným motívom nevystupuje v lexikálnom význame ako jeden z integrálnych sémantických komponentov, ale tvorí súčast' obsahu lexikálnej jednotky a má povahu fakultatívneho prvku v logickom spektre príslušného pojmu. Takýto prípad možno demonštrovat' na základe demotivovanej jednotky koláč. Pôvodne jednotka koláč označovala okrúhly výrobok („to, čo je ako kolo”), príznak okrúhly z lexikálneho motívu ([kolo]) však stratil dištinktívnu silu a ako fakultatívna noéma funguje len ako súčast' lexikálneho obsahu danej lexikálnej jednotky. J. Dolník (1995) ako periférnu vymedzuje pôvodnú motiváciu jednotky kôln̆a - to, že sa v minulosti stavali príslušné hospodárske budovy z kolov, je periférny informačný prvok (porovnaj Dolník 1995). O sémantickej deakcentácii komponentu z pôvodného motivantu komora v lexikálnom význame možno hovorit' v súvislosti s jednotkou komorná, pôvodný motív (pravdepodobne komorná je ,tá, ktorá bývala v komore”) sa periferizoval, synchrónny význam je „služobníčka na obsluhu šlachtičnej”. J. Dolník (1995) konštatuje, že v týchto prípadoch je demotivácia založená na tom, že pri utváraní daných jednotiek sa preferoval motív ako jeden z množiny možných príznakov (komorná), resp. sa preferoval motív s prechodnou výraznost'ou (záhrada, kôlňa, koláč). Ďalšie príklady z SKMS: sršat'-sršeň, červ - červený, l'úbit' - l'ubovník, pohan - pohánka, faklit'-fakl'a, rosa-rosnička.

c) Demotivácia spôsobená metaforizáciou sémantického príznaku inkorporovaného v pôvodnom slovotvornom základe

V tomto prípade sa demotivácia zakladá na metaforizácii príznaku, ktorý je inkorporovaný v pôvodnom slovotvornom základe a ktorý vystupuje ako diferenciačná séma lexikálneho významu v demotivovanej lexikálnej jednotke. Napr. ako homonymné spracúvame radixy v jednotkách hrdlo a hrdlačit', pričom jednotka hrdlačit' vykazuje zretel'nú štruktúrnu motiváciu, 
na základe ktorej možno jednoznačne stanovit’ slovotvornú štruktúru vymedzením slovotvorného základu a formantu. Demotivácia prebieha na úrovni lexikálnej motivácie, oslabenie motivačného vzt’ahu medzi motivátom a jeho pôvodným motivantom hrdlo je spôsobené metaforizáciou príslušných prvkov. Bázovým komponentom je tu séma [tažko] (,ako ked’ ide o hrdlo”), ktorá zároveň vystupuje ako diferenciačná séma v synchrónnom lexikálnom význame jednotiek. Spracovanie radixov ako homonymných, resp. polysémických nie je vždy jednotné. Ďalšie príklady z SKMS: kabát - prekabátit' - okabátit', bomba - bombastický, briliant - brilantný, família - familiárny, híbit'- híbat', hrot-vyhrotit'.

d) Demotivácia spôsobená kalkovaním z iného jazyka

$\mathrm{V}$ tomto prípade sa kalkované jednotky pričlenili do toho istého súboru radixov na základe analógie s jednotkou z iného jazyka, napr. rak-rakovina, driapat'sa-mrakodrap.

3. Tretia fáza demotivačného cyklu sa spája s vymedzením potenciálnych morfematických hraníc, ktoré sa naznačujú hranatými zátvorkami. Takúto segmentáciu uplatňujeme v prípade, ak dané segmenty majú dištinktívnu funkciu, napr. [hyper]bol- $a$, [para]bol- $a$, [para]lýz- $a$, [ana]lýz- $a$.

4. Finálna fáza demotivačného cyklu sa spája s perintegráciou, t. j. so stratou pôvodných hraníc medzi základom a formantom: v takomto prípade sa daná lexéma hodnotí v SKMS ako nemotivovaná, zakladá si vlastné slovotvorné hniezdo, a to $\mathrm{v}$ rámci osobitného súboru, v slovníku má takáto jednotka číselný index 8, resp. 7 a naznačuje sa ním synchrónna nesegmentovatel'nost' jednotky s nejasnou štruktúrou alebo so zastretou motiváciou. V súvislosti s analyzovanými javmi by bolo možné odlíšit' A) zastretie slovotvornej štruktúry bez výrazného oslabenia sémantického vztahu k pôvodnému motivantu (nedel'a - pondelok) a B) prípady zastretia formálnej i sémantickej súvzt’ažnosti s motivantom (môct' - nemehlo).

Perintegrácia vedie $\mathrm{k}$ extenzii počtu radixov, a to tak v domácich, ako aj v prevzatých jednotkách, porovnaj napr. radixy BIO (biofyzika), AERÓB (anareób), MIKRÓB (mikrób), porovn. tiež perintegráciu v domácich jednotkách jednoduchý JEDNODUCH, potmehúd POTMEHÚD, ježibaba JEŽIBAB. 
Od perintegrácie upúštame v prípadoch, ked' jeden z komponentov existuje aj ako samostatná lexéma (hit-paráda), na základe analógie výskytu daného radixu vo viacerých jednotkách (leuk-émia, leuk-o-cit, leuk-o-plast), $\mathrm{v}$ prípade delexikalizácie jedného z komponentov, ktorý tak plní funkciu systemizačného segmentu a má status afixoidu (-man v jednotkách: bar-man, fach-man, finiš-man, hajt-man).*

\section{Bibliografia}

BuzÁssyová K., JARošová A. (red.), 2006, Slovník súčasného slovenského jazyka. $A-G$, Bratislava: Veda.

DoLník J., 1995, Motivácia a lexikalizácia, Slovenská reč 60, s. 65-70.

DoLní J., 2003, Lexikológia, Bratislava: Univerzita Komenského.

Fundík J., 1993, Slovotvorná motivácia a jej jazykové funkcie, Levoča: Modrý Peter.

FuRDíK J., 1994, Integračné procesy pri lexikálnych prevzatiach, Jazykovedný časopis 45 , s. $95-102$.

Furdík J., 2008, Teória lexikálnej motivácie, M. Ološtiak (red.), Košice: Vydavatel'stvo LG.

Mаснек V., 1968, Etymologický slovnik jazyka českého, Praha: Academia.

OlošTiaK M., 2007, Interlingválna a slovotvorná motivácia, Jazykovedný časopis 58, s. $103-112$.

Sokolová M., Ivanová M., Dziaková K., 2003, Zásady spracovania slovníka koreňových morfém slovenčine, Jazykovedný časopis 54, s. 67-82.

Sokolová M., GenČI J., 2006, Štatistické spracovanie apelatívnych radixov, w: M. Sokolová, M. Ivanová, M. Ološtiak (red.), Morfematický výskum slovenčiny (možnosti jeho štatistického, elektronického a didaktického spracovania), Prešov: FF PU, s. 27-56.

Sokolová M., Ološtiak M., Ivanová M. et al., 2007, Slovník koreňových morfém slovenčiny (2., upravené vydanie), Prešov: FF PU.

\section{Synchrony and diachrony in Slovak Dictionary of Root Morphemes}

( s u m mary)

In the paper the author describes the dynamics of the word formation processes and their representations in Slovnik koreňových morfém slovenčiny (2007). Demotivation processes have several degrees reflected in the dictionary through various 
lexicographical tools of description. Depending upon the measure, semantic or formal decorrelation between two units leads to the existence of radix polysemy, delimitation of potential morphematic boundaries, or perintegration in primary word formation structure. 